\title{
A Future for Borneo's Wildlife?
}

\section{By Tom Harrisson}

Independence for Malaysia and the resulting hostilities with Indonesia have led to changes affecting wildlife as well as humans and not always for the worse. Not only was the smuggling of animals via Singapore stopped dead, which particularly affected orang utans, and the sale of firearms and ammunition drastically controlled, with already noticeable effects on some animal populations, but the new leaders feel strongly about national assets going out of the country, whether antiques or animals, with the result that more has been done for wildlife in the past two years than in decades before. The real killer, says the author, who is Curator of the Sarawak Museum, is timber felling with vastly accelerated techniques which take machines up to $1000 \mathrm{ft}$. and lay whole jungles by the square mile a day.

BORNEO has one of the world's richer faunas, notably in the field of primates large and small, rain forest birds, and reptiles, and a markedly distinctive montane life at high altitudes culminating on Mt. Kinabalu, 13,454 ft. (highest in SE Asia) with some genera and species confined to a few summit square miles. Since I last summarised the situation* there has been a revolution, starting in Brunei, in what was then British Borneo. Two states, Sarawak and Sabah, together with Singapore have become parts of the Federation of Malaysia (1963), thus arousing Indonesian hostility which has developed into armed "confrontation" along the thousand-mile inland border with the larger part of the island, Indonesian Kalimantan. These major changes have profoundly affected the present and future ecology of Bornean life as a whole; four important changes have so far proved favourable to wildlife interests on the whole, but two others seriously hinder them. First, Indonesian "confrontation" suddenly closed a thousand miles of internal border in Borneo, crossed by innumerable overland barter routes in the past. At the same time, the massive sea traffic to Singapore, much of it in small sampan boats, was stopped dead. This at one stroke cut the main lines for traffic in animals, nearly all illegal, and especially orang utans. Secondly, Singapore's Prime Minister Lee Kuan Yew introduced tighter controls on smuggling in 1964-5, partly as a result of our representations. Hong Kong had reacted similarly in 1962-3, so that now mainly Bangkok remains decreasingly an "open pipe-line", but in this case mainly for aerial smuggling of a few rare animals carried on false manifest identifications.

The importance of Singapore's great free port, at the cross roads of South-east Asia, affects not only Borneo but the whole region. After careful study we estimate that for 1946-64 not fewer than 2,000 orang utans alone passed through Chinese, Indian, Eurasian and

- ORYX, 1961, pp. 126-130; Malayan Nature Journ. 16, 1962, 1:6-8. 
American dealers based there---some of them horribly ignorant and inexperienced, at the level of third-rate petshops or simply dope smugglers. Even according to official figures which Singapore provided to the 1964 IUCN Symposium (Paper No. 3, p. 47), we find:

\section{Category: Monkeys/Apes/Gibbons \\ 1963: Official Import Total ........... 871 \\ Official Export Total $\ldots \ldots \ldots \ldots \ldots 1,985$ \\ Difference $\ldots \ldots \ldots \ldots \ldots \ldots \ldots . \ldots \ldots 1,114$}

As there are virtually no endemic wild primates in the State of Singapore, the difference can only be attributed to animals other than common monkeys (not worth the trouble) smuggled in. These were mostly orang utan, simiang and the rarer monkeys. The figures take no account of others smuggled out-mainly via Bangkok.

Despite active and high level sympathy, the legal situation in Singapore and throughout the area remains complex and sometimes inoperable. In January 1965 the government could do nothing in support of public protests at the display of an adult tapir Tapirus indicus in a pen at the New World's Night Funfair in Singapore, although the animal is fully protected in Malaya and had been brought across the Straits of Johore to Singapore (all within Malaysia) without licence. The Chinese owner was within his rights, so long as a cruelty standard (unspecified for tapirs) was not reached.

The third favourable factor is also a by-product of Indo-Malaysian confrontation. The previously almost uncontrolled sale of firearms and ammunition, which had reached truly murderous levels especially in Sarawak, (cf. ORYX 1961: page 126), has been drastically curtailed and controlled since early 1963. Whereas by 1962 even the smaller squirrels, pigeons and mouse deer were becoming scarce in Dayak areas, in many places there has been a significant recovery since. Larger forms that were being hunted to death and are now slowly recovering, at least locally, include several hornbills, the Argus Pheasant $A$. grayi (which in 1950 could be heard everywhere but barely anywhere in 1960), the gibbon, Hylobates moloch, and leaf monkeys, Presbytis, especially the handsome red rubicundus, often mistaken for orang by the inexpert.

The fourth favourable factor is that a new race of leaders and administrators is emerging who know a lot more about the country and feel more possessive about its native features than did all but the odd individual in otherwise adequate expatriate officialdom. There is a particular feeling about removing "national assets", whether antiques or animals "to the west". Preoccupied as they are with political and economic urgencies, these leaders still need stimulation and pressure from the enthusiastic minority within and expert advice (offered tactfully-more tactfully than has always been the case to date) from outside. Yet, on the whole, more has been done for wildlife from the top in the past two years of independence than in decades before. In July 1964, strong new conservation legislation was finally enacted in Sabah and, what is more important, has been 
enforced by the courts - even to a heavy fine on a Dayak in April this year for possessing two live fireback pheasants Lophura ignita. Sabah has also established the whole upper slopes of Mt. Kinabalu as a National Park, largely through the encouragement of Dr. E. J. H. Corner of Cambridge and the two Royal Society Expeditions he led there. In Sarawak, the game laws have been extended, and the State government has given my wife invaluable help and encouragement in allocating a large slice of the Bako National Park to her ape-release project. Forestry are also gazetting several new national park areas, including one round the Niah Caves.

On the obverse side, a lesser misfortune for wildlife has been the renewal after a long break of friendly relations between the Netherlands and Indonesia which has given an alternative though more costly route for animal smuggling. This looks like growing, via Rotterdam and the Hague. Despite the gallant efforts of Dr. A. C. V. van Bemmel and others, illegal shipments of rare animals from Indonesian Borneo and elsewhere are not only coming immunely into the land of the World Wildlife Fund's President, Prince Bernhard, but being re-routed thence to Germany, the USA and elsewhere.

The Scramble for Timber

But perhaps a greater danger and the real killer is the accelerating rate and changing techniques of massive timber extraction, probing far inland and up to 1,000 feet, obliterating some of the world's largest remaining virgin jungles, no longer tree by tree but at the rate of square miles a day. Timber is the largest single revenue source for Borneo as a whole. The scramble for it intensifies.

About 75 per cent of our endemic fauna lives in the rain forest below the 3,000 ft. contour, including over 250 bird species, 100 mammal, 150 reptile and frog (3 new species found recently) and still unnumbered invertebrates. The increasing use of powerful herbicides now threatens these additionally, in that the natural post-felling replacement cycle is being sacrificed to "commercial" timbers and spaced-out growth, which in itself is alien to the whole biotope of multi-mixed canopy forest (so well described in Dillon Ripley's new Life "Nature Book" for the region). All arboreals, and especially larger forms like the clouded leopard Neofelis, civet cats and the hole-nesting birds, hornbills, barbets, woodpeckers, etc., as well as scrub and terrestrial life of all kinds balanced under the present canopy pattern (e.g. tree shrews, babblers, pheasants and partridgesof which we have some splendid specialities) must all be affected. The problem is approaching such a scale as to deserve international study for the whole region from Burma through to Philippines and Celebes. In Sabah, especially, it is already menacing for Borneo.

A few animals are likely to benefit from new style "reforestation", notably the Indian elephant, probably feral in Borneo and only found in north-east Sabah. The 1965 elephant population is estimated at $2,000+$ (Peter Burgess et al.). This is already big enough to arouse the hostility of new agricultural interests, such as oil-palm-which it 
rates delicious. The wild ox Bos lowi, reduced by indiscriminate shooting in the fifties, also favours this type of "open forest", and is now only numerous on the curious open grasslands of the remote upper Bahau in NW Kalimantan, with an estimated 100 within 500 square miles, (1963; see map in Geographical Journal, 1964, p. 332).

The general picture is dim but not hopeless. The specific picture for some animals of great interest varies from bright to black. Worst of all is the two-horned rhinoceros $D$. sumatrensis, for which Borneo was long regarded a reservoir area. I have been at much pains to seek every level of native and official information from all corners of the island since 1961. My estimate for May 1965 is as follows:

Kalimantan - 10 (25), all in the north centre.

Sabah - 11-13, all but one on the north-east.

Sarawak and

Brunei - Rejang basin.

There has been only one recent report of two animals within contact range, and none of babies or young since 1957 .

\section{A Monkey That Thrives}

Also on land, the megapode, $M$. freycinet, which nests in mound excavations on the Sabah and Kalimantan islets, has been heavily reduced by increased motor boat (and pirate camp) use of these in recent years, though Sabah are now strengthening a previously sketchy egg-sale control system. The darter, $A$. anhinga, is similarly plagued by a vast rise in the use of outboards for river travel, and is now never seen as once it was "round the next bend" on most of the great rivers; it hangs on in the wilder big valleys, notably again in NE Sabah, where the great Kinabatangan and Segama systems are still very sparsely populated. The unique and splendid proboscis monkey Nasalis larvatus, on the other hand, now almost ignores the many motor boats and even speed boats which thread the coastal labyrinth of mangrove swamp, where it has further increased and is now locally abundant and tame. Fortunately, it has defied all zoos except San Diego by its selective (though voracious) food habits and delicate metabolism, and so has never been subject to the commercial quest. James A. Kern made a useful study of the Brunei Bay population in 1962-3 (see Zoologica, 49, 1964, 3:183).

We have made two notable "rediscoveries" of forms previously thought to be exceedingly rare or extinct. The Bornean peacock pheasant Polyplectron schleiermacheri, never seen alive in the wild, was quite clearly well-known, and present in small numbers around the 1,000-3,000 ft. levels, to a group of nomadic Punans who roam a vast uninhabited jungle sector of the upper Rejang where I contacted them by helicopter and worked with them for two periods early in 1965. They describe habits, nesting and calls accurately, and I bope to make a sepcial visit to seek and observe this curious bird with them presently. It was probably from this part of Borneo that Beebe obtained, at third hand, the distinctive feathers on which knowledge of the bird was mostly based. 
The other rediscovery has already attracted world interest, since it involves a reptile of peculiar concern to biologists as an evolutionary "missing link" between snakes and lizards. The Borneo earless monitor Lanthanotus borneensis commands a special family of its own (nearest to the American gila monsters), and was known from a few native collected specimens decades ago. We found the first live one, in a muddy hole, near the Niah Caves in 1959. Kept alive, it showed remarkable habits of lethargy, nocturnalism, fossorialism and eggeating which, once understood, led to unearthing many others over a wide belt of 250 miles on the sub-coastal plain of West Borneo.

At one time we had eight alive and thriving in our Kuching home (cf. Nature, 1961, vol. 190, No. 4782, page 1213). But of the numbers sent to zoos and laboratories at their urgent request, all have soon died except two given to the doyen of European herpetologists, Professor R. Mertens, who has now kept them nearly three years at Frankfurt. They may well live to a hundred?

At sea, the magnificent white-bellied sea eagle Haliaeëtus leucogaster has increased, as the result of arms control-"sportsmen" loved to take a pot shot. But the long-term outlook for our three species of great turtle-green, loggerhead and hawksbill-continues distressing (cf. ORYX, 1962, page 265), for slaughter reasons outside our territorial control. A new menace is the increase in Japanese trawler activity and their interest in catching hawksbill, hitherto the least molested, for a revived trade in "real tortoiseshell". More hopefully, Sabah has joined the well-established Sarawak scheme of conservation hatching and rearing, and we exchanged personnel and ideas to this end through 1964.

\section{A Survey of the Dugongs}

The gentle dugong Sirenia has not been reported along the west coast for some years, and is said to be slaughtered on sight by protein-hungry Indonesians all along the south and south-east. There are still a number present in the north-east, and one was exposed for sale in Sandakan market as late as April 1965, despite Sabah legal protection. The difficulty is to prove deliberate killing, as new type of nylon and wire nets do indeed catch much which was hitherto immune from the fishermen-turtles and dolphins along with dugongs. It is hoped to make a fuller survey of Sabah dugongs in the near future, as it could be saved in these waters perhaps more effectively than anywhere else now that the Ceylon position is so insecure.

Last, saddest, most persistent in Borneo is the case of the orang utan. I was appointed Chairman of the Survival Service Commission's special orang utan group at Nairobi late in 1963, and my wife Barbara, Hon. Secretary of the associated Orang Utan Recovery Service (OURS), supported by funds from some of the world's best zoos (in the British Isles; Chester and Dublin). Since then wemostly she-battle on paper and sometimes nearer the ground, with politicians, poachers, pirates, professors and phoneys in an agonising 
sequence of obstacle-races which have taken me one and a half times round the world, and my wife up into the trees!

The basic and continuing trouble is that the orang is too nice for its own good. Superficially near-human, lovable and (once captured) placid, it has become a zoo "must", and, much more recently, favoured material for medical and now for advanced physical research. Wellestablished, powerful, sophisticated and sometimes secretive interests therefore seek to continue the orang trade at, almost literally, any price. Right now, certain institutions will pay $£ 1,000$ for a healthy juvenile; if really necessary, they would no doubt fork up $£ 5,000$. Set against massive deflation and near-starvation in Indonesian Borneo (and Sumatra), the incentive to export is almost inconceivably high to the western eye. Although the scale of reward cataracts down towards the source, nevertheless he who can shoot a mother and catch her baby (the only easy way to get this ape at all), and smuggle it out to an agent, can secure his family's diet and health for years in one gesture. Now, with the general controls tightened in Singapore and Hong Kong as well as at Sabah and Sarawak sources, the smuggled trade has been reduced from the 1962 avalanche-at least temporarily. The question today is: do enough orangs remain in a wild state to survive? In Borneo, careful studies with improved field methods and information, indicate a population not above 2,500 . But this is heavily overweighted, because of mother poaching, towards older males, many of which are isolated, while more viable social groups are of ten cut off in small forest areas or by river divides (orangs love water but can't swim). The largest stretches of orang country, free from immediate threat of Indonesian armed infiltration, Dayak or timber felling, are in north-east Sabah.

After years of sending confiscated orphans to world zoos, with unsatisfactory (and often lethal) results, my wife's project to train them back into their native wild, based on Bako National Park, has during the past three trying years succeeded to the extent that in late April 1965 we moved some ex-orphans 600 miles by launch to Sepilok Forest Reserve in Sabah. Many heartaches remain to be borne, yet this project may hold a hope to augment the pure stock of native orangs, superb arboreal aristrocrats who bear about as much relation to the cage zoo version as the charming editor of this ORYX does to a chronic-imbecile-deafmute.

The orang is a top example of a much deeper headache, of course. Profitable commercial demand for rare animals, dead or alive, away from their homelands, produces a situation that can seldom be countered by remote Asian countries with limited resources, however good the will. And so long as this demand exists and produces a profit-taking traffic, it is almost impossible to expect new, small tropical countries and poor people to believe that world conservation, as enunciated from Morges or Washington, is serious, truthful or disinterested. In this way, not only rare animals but ALL animals are damned by the new merchants of living death. 



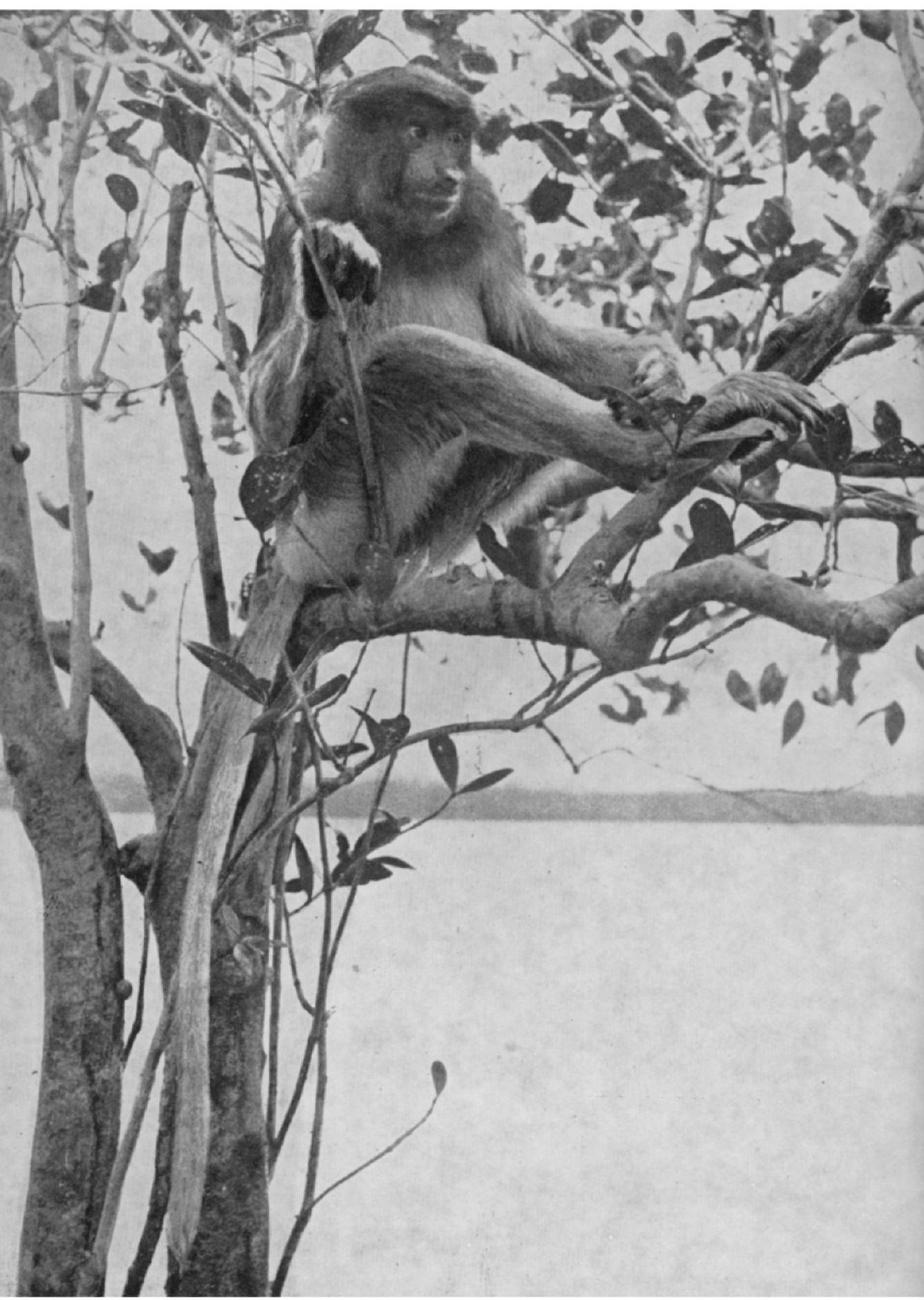

Plate 10. Proboscis Monkey, confined to Borneo and one of the few animals to have increased in recent years. 


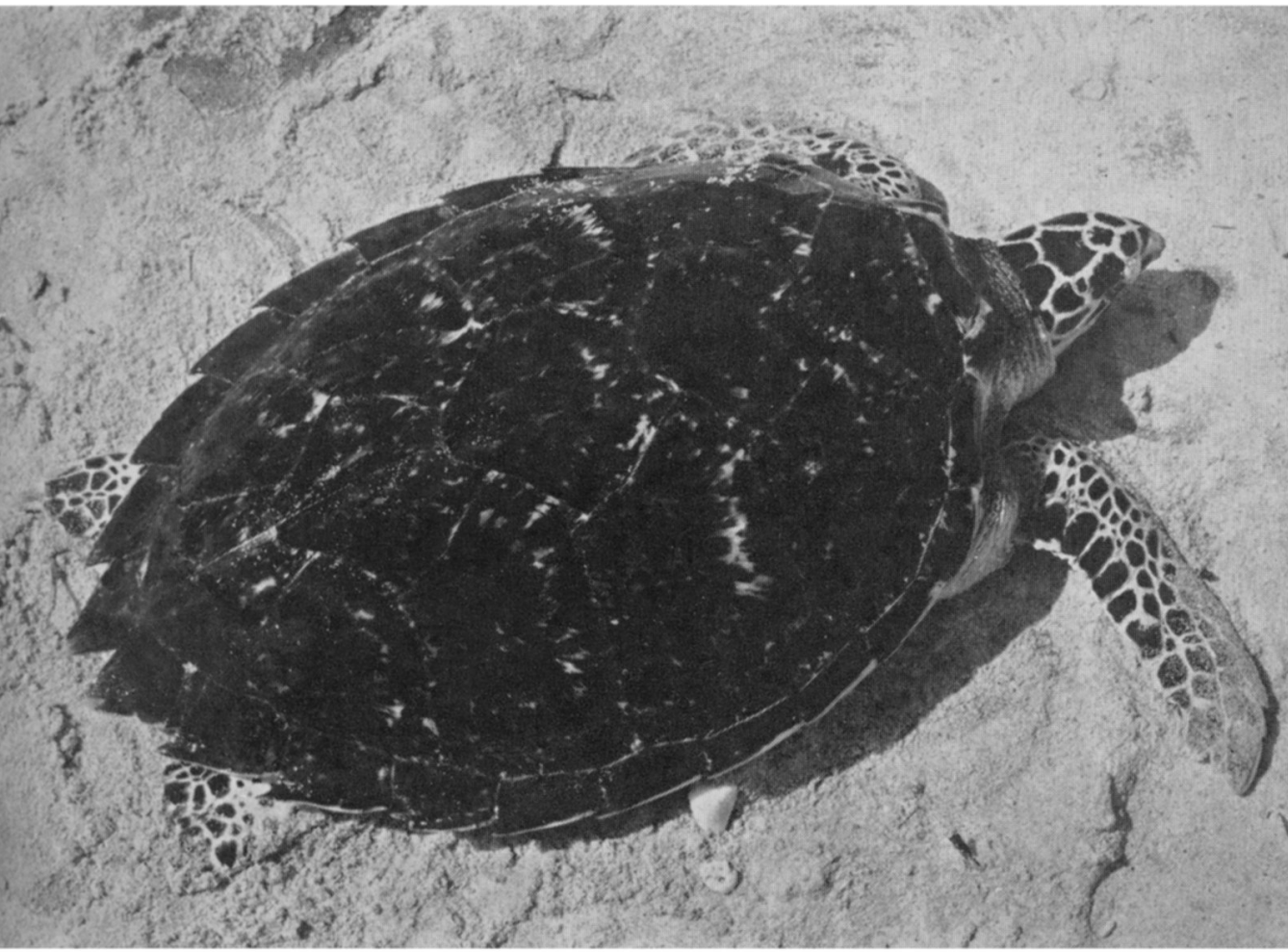

Plate 11. Hawksbill Turtle, seriously threatened by the Japanese shell trade.

\section{THE WILDLIFE OF BORNEO}

Plate 12. Borneo Earless Monitor Lizard, one of the world's rarest reptiles, rediscovered in Sarawak in 1959. Length 13 ins.

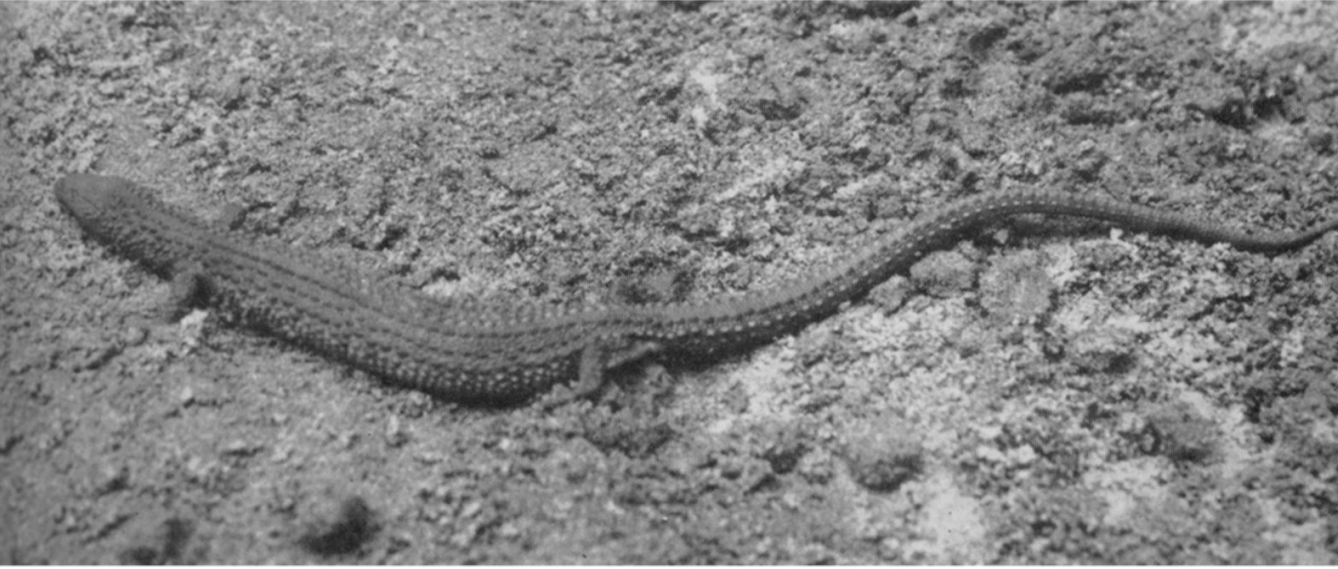




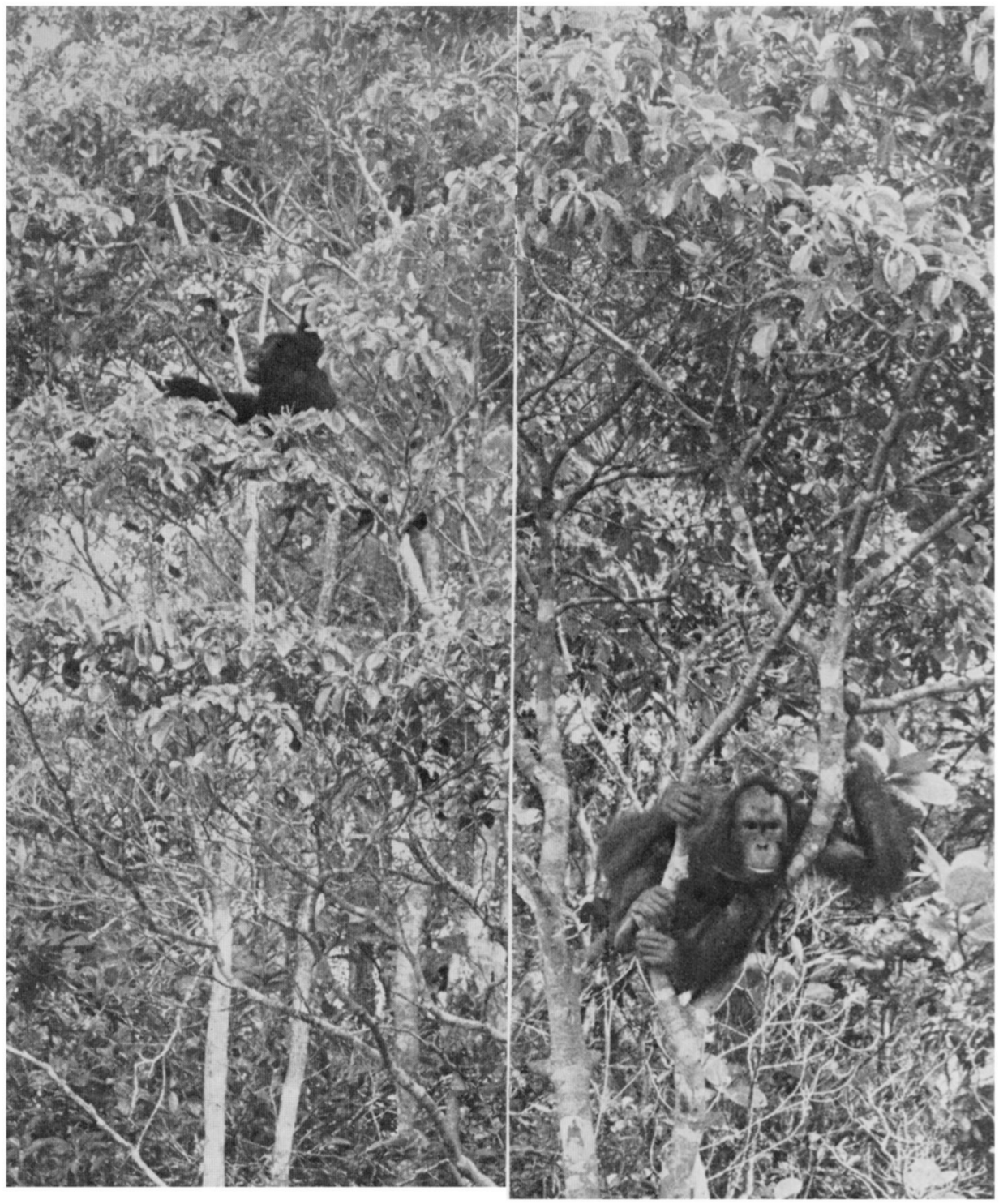

Plate 13. AIRBORNE. Arthur and Cynthia, two of the released orang utans while in the
Bako National Park. 


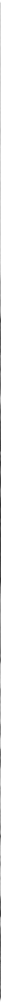

\section{SICNS OF THE TIMES IN HONG KONG}

Plate 14: Levelling hillsides for building at Tsun Wan, New Territories. The debris is used to reclaim land from the sea. Because modern machinery has made it possible to develop hitherto unworkable sites in Hong Kong, urban areas are spreading, and the pressure on wildlife is increasing. In an article on page 107 two members of the University of Hong Kong describe the plans that are being made to create a national park and set aside nature reserves while there is still time. 


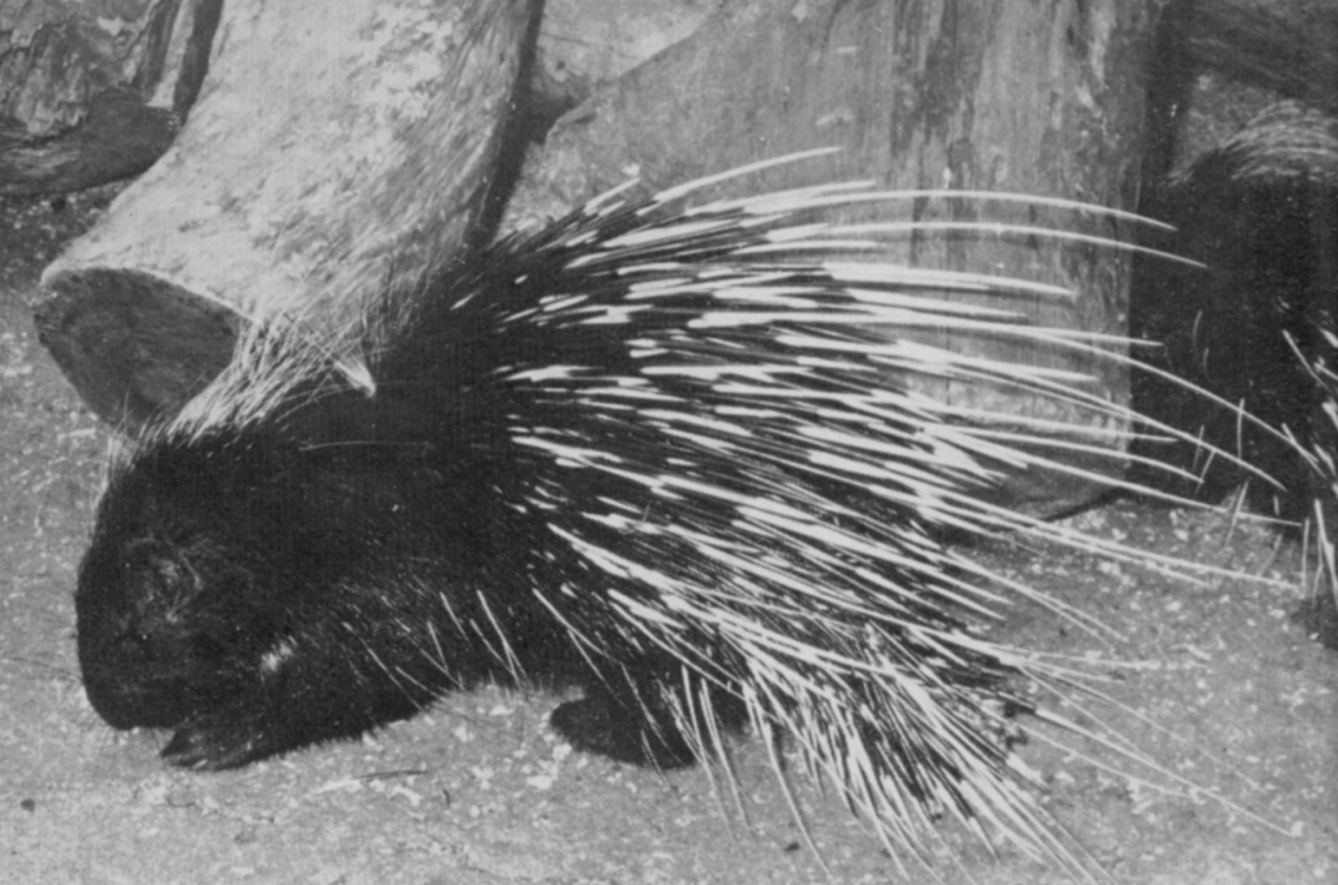

Plate 15. Crestless Himalayan porcupine photographed in the Botanical Cardens, Hong Kong.

Plate 16. Chinese ferret-badger trapped on Hong Kong Island.

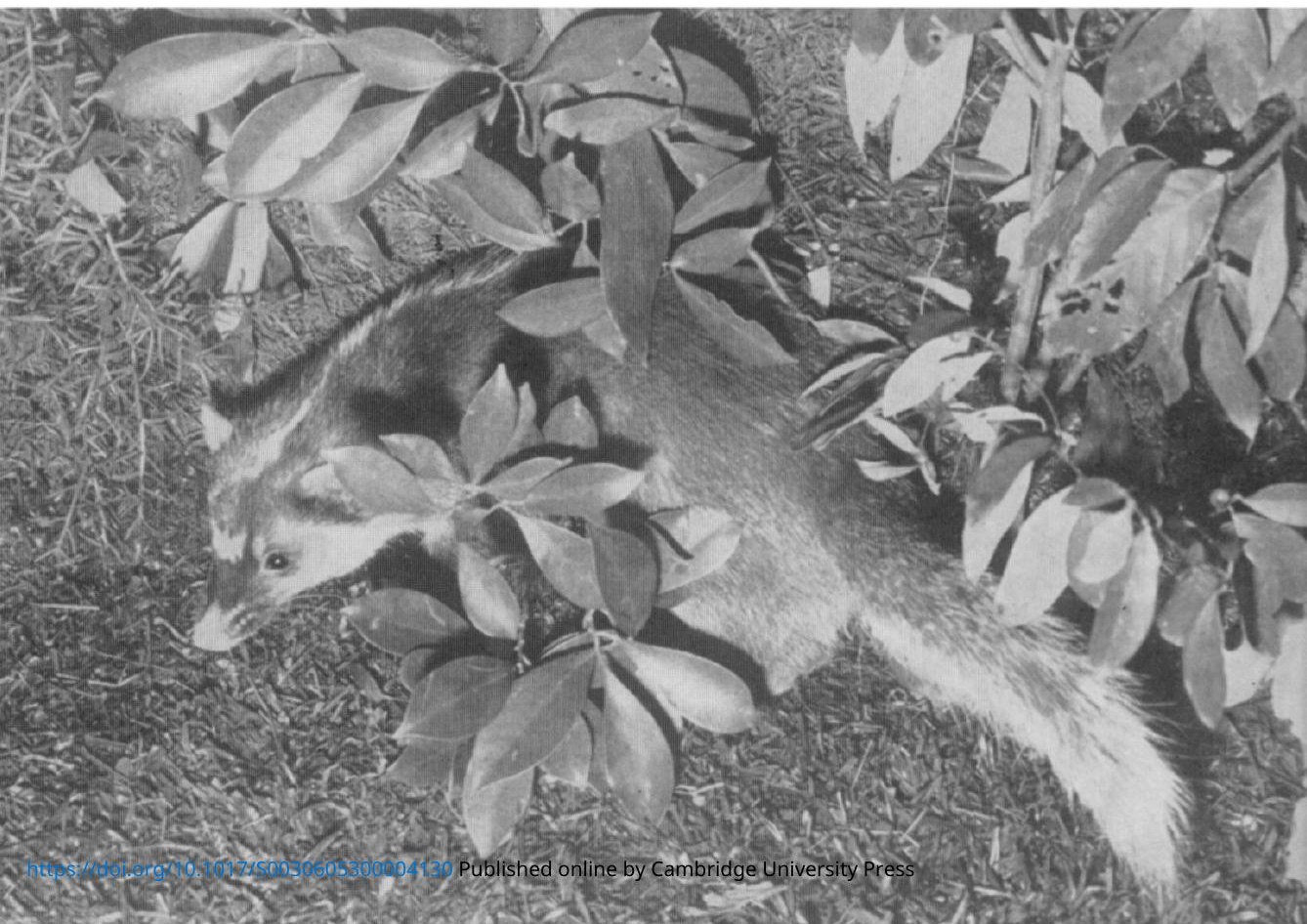


Plate 17. Chinese pangolin captured by workmen in the New Territories and here being released on Hong Kong Island.

THE WILDLIFE

OF HONC KONG

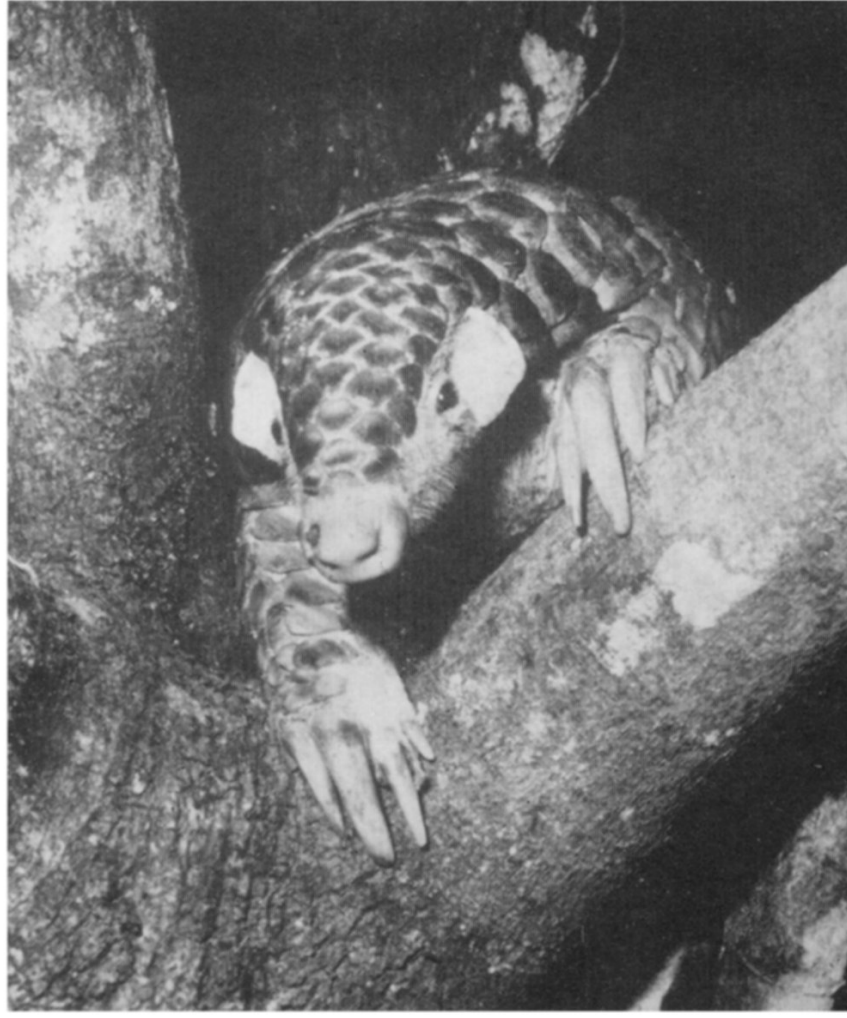

Plate 18. Crab-eating mongoose. These two mongooses are now in the London Zoo.

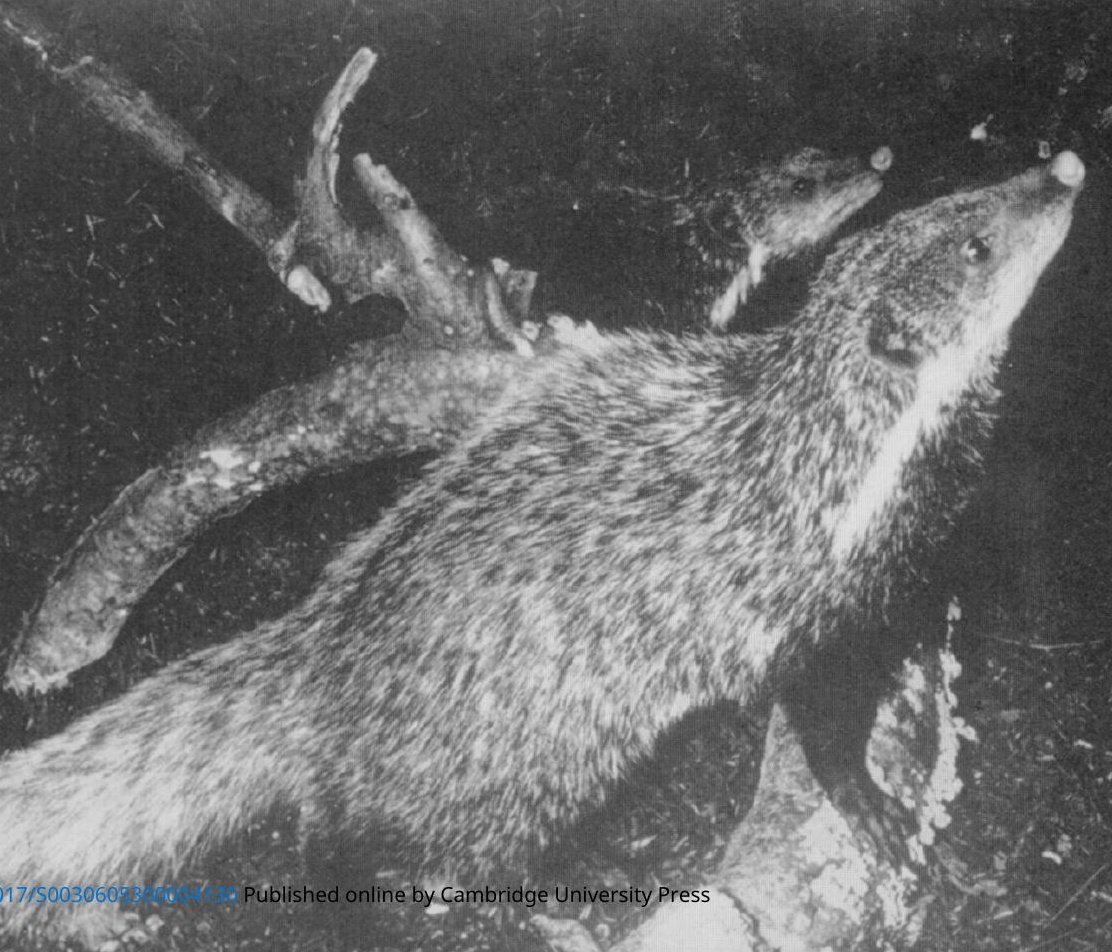




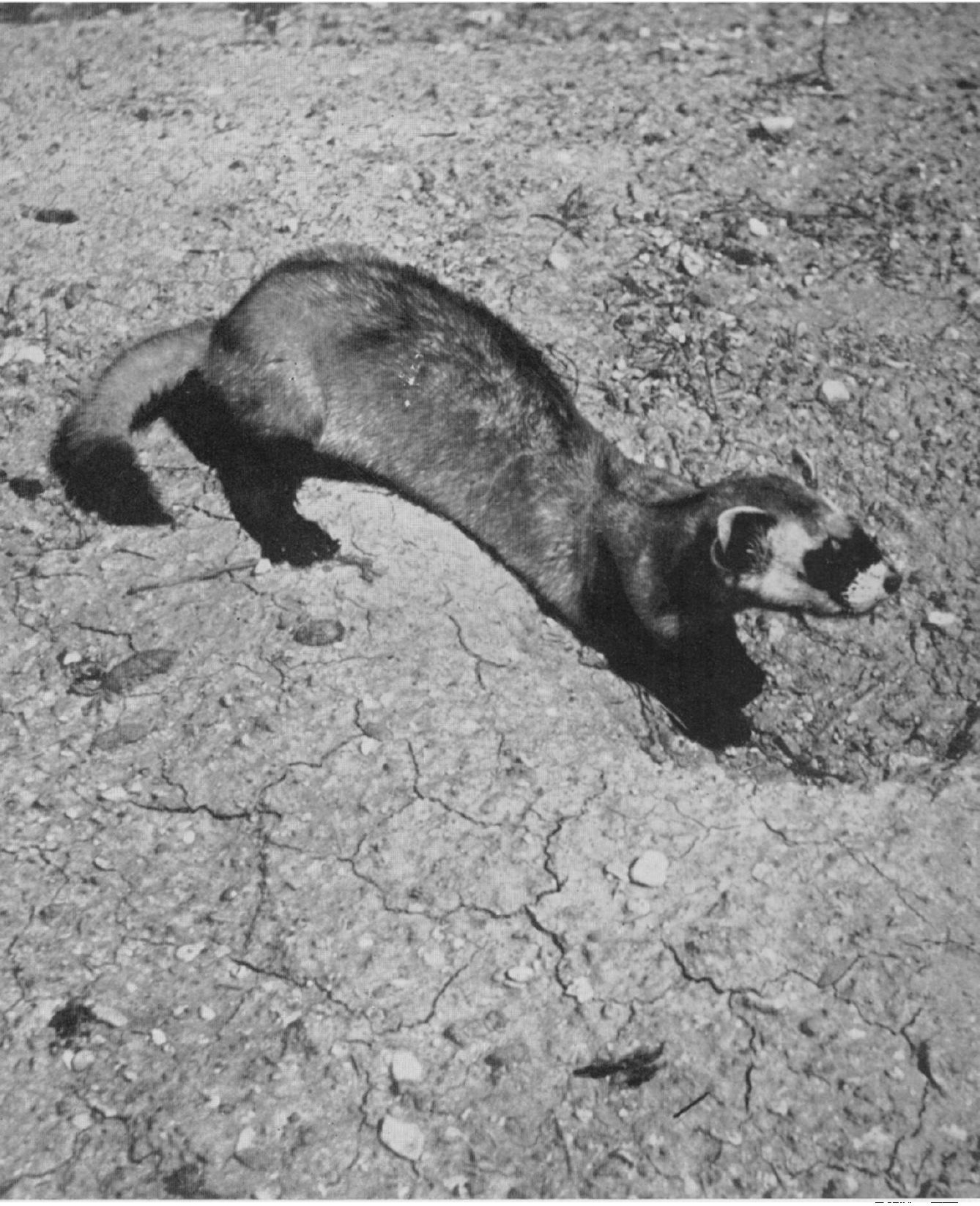

Walt Disney Productions

\section{THE BLACK-FOOTED FERRET}

Plate 19. This photograph of one of America's rarest animals is taken from the Walt Disney film, "Vanishing Prairie," and kindly loaned by Walt Disney Productions. 